\title{
Prepartal dietary energy level affects peripartal bovine blood neutrophil metabolic, antioxidant, and inflammatory gene expression
}

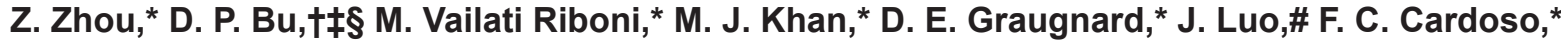 \\ and J. J. Loor*1 \\ *Department of Animal Sciences and Division of Nutritional Sciences, University of Illinois, Urbana 61801 \\ †State Key Laboratory of Animal Nutrition, CAAS-ICRAF Joint Laboratory on Agroforestry and Sustainable Animal Husbandry, \\ Institute of Animal Science, Chinese Academy of Agricultural Sciences, Beijing, 100193, P. R. China \\ $\ddagger$ World Agroforestry Centre, East and Central Asia, Beijing 100081, China \\ $\S$ Synergetic Innovation Center of Food Safety and Nutrition, Harbin, 150030, China \\ \#College of Animal Science and Technology, Northwest A\&F University, Yangling, Shaanxi, 712100, P. R. China
}

\begin{abstract}
During the dry period, cows can easily overconsume higher-grain diets, a scenario that could impair immune function during the peripartal period. Objectives were to investigate the effects of energy overfeeding on expression profile of genes associated with inflammation, lipid metabolism, and neutrophil function, in 12 multiparous Holstein cows ( $\mathrm{n}=6 /$ dietary group) fed control [CON, $1.34 \mathrm{Mcal} / \mathrm{kg}$ of dry matter (DM)] or higher-energy (HE, $1.62 \mathrm{Mcal} / \mathrm{kg}$ of DM) diets during the last $45 \mathrm{~d}$ of pregnancy. Blood was collected to evaluate 43 genes in polymorphonuclear neutrophil leukocytes (PMNL) isolated at $-14,7$, and $14 \mathrm{~d}$ relative to parturition. We detected greater expression of inflammatory-related cytokines (IL1B, STAT3, NFKB1) and eicosanoid synthesis (ALOX5AP and PLA2G4A) in HE cows than in CON cows. Around parturition, all cows had a close balance in mRNA expression of the pro-inflammatory $I L 1 B$ and the anti-inflammatory IL10, with greater expression of both in cows fed HE than CON. The expression of CCL2, LEPR, TLR4, IL6, and $L T C 4 S$ was undetectable. Cows in the HE group had greater expression of genes involved in PMNL adhesion, motility, migration, and phagocytosis, which was similar to expression of genes related to the pro-inflammatory cytokine. This response suggests that $\mathrm{HE}$ cows experienced a chronic state of inflammation. The greater expression of G6PD in HE cows could have been associated with the greater plasma insulin, which would have diverted glucose to other tissues. Cows fed the HE diet also had greater expression of transcription factors involved in metabolism of long-chain fatty acids (PPARD, RXRA), suggesting
\end{abstract}

Received September 3, 2014.

Accepted April 8, 2015.

${ }^{1}$ Corresponding author: jloor@illinois.edu that immune cells might be predisposed to use endogenous ligands such as nonesterified fatty acids available in the circulation when glucose is in high demand for milk synthesis. The lower overall expression of SLC2A1 postpartum than prepartum supports this suggestion. Targeting interleukin-1 $\beta$ signaling might be of value in terms of controlling the inflammatory response around calving. The present study revealed that overfeeding cows during late pregnancy results in activation, ahead of parturition, of PMNL responses associated with stress and inflammation. These adaptations observed in PMNL did not seem to be detrimental for production. Key words: dietary energy, polymorphonuclear neutrophil, gene expression

\section{INTRODUCTION}

On average, $16.5 \%$ of cows in the US dairy cattle industry experience clinical mastitis (USDA, 2008). Once a pathogen is detected by the receptors in the epithelial cells of the mammary gland, the acute-phase reaction begins and the immune system is activated to eliminate the pathogen (Oviedo-Boyso et al., 2007). Polymorphonuclear neutrophil leukocytes constitute up to $70 \%$ of the circulating white blood cells in sick bovine compared with 30 to $40 \%$ in healthy animals (Goldsby et al., 2000). In fact, after initiation of an inflammatory response during an infection, PMNL provide the first line of defense against the invading pathogens, especially those causing mastitis (Paape et al., 2003) and become the predominant cell type observed (Sordillo et al., 1997).

During the transition period, the increased nutrient demand, the decrease in DMI, and the drastic changes in endocrine status (e.g., increased estrogen) can give rise to metabolic disorders and suppressed functions of immune cells (Grummer, 1995; Mallard et al., 1998). The latter are characterized by impaired neutrophil trafficking, phagocytosis, and killing capacity (Kehrli 
et al., 1989), which could eventually lead to increased susceptibility to mammary infections. In addition, the cytokine and hormonal changes (e.g., glucocorticoids) in the transition period are also closely linked to neutrophil development and immunity-related activities, the mechanism of which remains to be elucidated (Burton et al., 2005).

The level of energy consumption prepartum also may be a determinant factor for inflammatory status of cows. For instance, feeding higher-grain diets during the dry period may lead to overconsumption of energy from carbohydrates (Dann et al., 2006). One week postpartum, serum NEFA concentrations were greater in cows fed high-energy diets ad libitum than in cows fed a control diet with more straw to help regulate gut fill and maintain consistent intake (Khan et al., 2014).

At chronically elevated concentrations, NEFA led to a reduction in PMNL viability, which could impair the immune response to pathogens (Scalia et al., 2006). Although PMNL function can be measured through traditional neutrophil function tests, gene expression technology enables us to explore how PMNL cells respond to the intensity of lipid mobilization as a way to understand effects of dry-period nutritional management on immune cell function at a molecular level.

We hypothesized that a high level of dietary energy intake induces body deposition and high concentrations of NEFA postpartum, serving in part to alter PMNL gene expression during the periparturient period. Specifically, the objectives were to determine gene expression of 43 inflammatory and lipid metabolism markers (Table 1) in PMNL in cows fed a high- or low-energy level diet in the prepartum period.

\section{MATERIALS AND METHODS}

\section{Animals and Diets}

Cows used in the present study were from the experiment of Khan et al. (2014) and were free of clinical disease throughout the study. Briefly, one group of cows was fed a diet providing at least $100 \%$ of calculated $\mathrm{NE}_{\mathrm{L}}(\mathbf{C O N} ; 1.34 \mathrm{Mcal} / \mathrm{kg}$ of DM), whereas the other group was fed with a diet providing $>140 \%$ calculated $\mathrm{NE}_{\mathrm{L}}(\mathbf{H E} ; 1.62 \mathrm{Mcal} / \mathrm{kg}$ of DM) during the entire $45-\mathrm{d}$ dry period. Diets were fed as TMR once a day (0600 h) using an individual gate feeding system (American Calan, Northwood, NH). Cows were housed in a ventilated enclosed barn during the dry period. After parturition, all cows were moved to a tiestall barn and fed a common lactation diet $\left(\mathrm{NE}_{\mathrm{L}}=1.69 \mathrm{Mcal} / \mathrm{kg}\right.$ of $\left.\mathrm{DM}\right)$ as TMR daily $(0600 \mathrm{~h})$ and milked twice daily (0400 and $1600 \mathrm{~h})$.

\section{PMNL Isolation}

Samples of blood $(\sim 120 \mathrm{~mL})$ were collected at $\sim 0700$ $\mathrm{h}$ from the coccygeal vein or artery with evacuated tubes containing acid citrate dextrose (ACD Solution A; Fisher Scientific, Pittsburgh, PA) at $-14 \pm 2,7$, and $14 \mathrm{~d}$ relative to parturition. After blood collection, tubes were placed on ice $(\sim 30 \mathrm{~min})$ until isolation (Moyes et al., 2009). Samples were centrifuged at 600 $\times g$ for 15 min at $4^{\circ} \mathrm{C}$. The buffy coat and approximately one-fourth of the red blood cells were removed and discarded. The remaining sample was poured into a 50-mL tube. Twenty milliliters of deionized water at $4^{\circ} \mathrm{C}$ was added to lyse red blood cells followed by addition of $5 \mathrm{~mL}$ of $5 \times \mathrm{PBS}$ at $4^{\circ} \mathrm{C}$ to restore an iso-osmotic environment. Samples were then centrifuged at $200 \times g$ for $10 \mathrm{~min}$ at $4^{\circ} \mathrm{C}$. Subsequently, samples were washed with $1 \times$ PBS and re-collected by centrifugation at 500 $\times g$ for 3 min at $4^{\circ} \mathrm{C}$ three times. The isolated PMNL were immediately homogenized in $2 \mathrm{~mL}$ of TRIzol reagent (Invitrogen, Carlsbad, CA) with $1 \mu \mathrm{L}$ of linear acrylamide (Ambion Inc., Austin, TX) using a Polytron power homogenizer (Kinematica, Bohemia, NY) at maximum speed. The suspension was then transferred equally into 2 RNA-free microcentrifuge tubes $(2 \mathrm{~mL}$; Fisher Scientific) and stored at $-80^{\circ} \mathrm{C}$ until further analysis.

\section{RNA Isolation}

The suspension of RNA and TRIzol reagent was thawed and, upon centrifugation, total RNA was separated with chloroform followed by acid phenol:chloroform (Ambion Inc.). Total RNA was then precipitated with isopropanol, and the RNA pellet was cleaned with $75 \%$ ethanol before reconstitution in RNA storage buffer (Ambion Inc.) for storage at $-80^{\circ} \mathrm{C}$. Purity of RNA was confirmed by optical density $(\mathrm{OD})_{260 \mathrm{~nm}} / \mathrm{OD}_{280 \mathrm{~nm}}$ (NanoDrop ND-1000, NanoDrop Technologies, Rockland, DE). Quality of RNA evaluated via RNA integrity number (RIN) in the 2100 Bioanalyzer (Agilent Technologies Inc., Santa Clara, CA) was $7.7 \pm 0.2$.

\section{Quantitative PCR Analysis}

All procedures were as reported previously (Moyes et al., 2014). Briefly, cDNA was synthesized using $100 \mathrm{ng}$ of RNA, $1 \mu \mathrm{g}$ of dT18 (Operon Biotechnologies, Huntsville, AL), $1 \mu \mathrm{L}$ of $10 \mathrm{mmol} / \mathrm{L}$ dNTP mix (Invitrogen Corp., Carlsbad, CA), $1 \mu \mathrm{L}$ of random primers (3 mg/ $\mu \mathrm{L}$; Invitrogen Corp.), and $10 \mu \mathrm{L}$ of DNase-/RNasefree water. The mixture was incubated at $65^{\circ} \mathrm{C}$ for 5 min and kept on ice for $3 \mathrm{~min}$. A total of $6 \mu \mathrm{L}$ of master mix, composed of $5.5 \mu \mathrm{L}$ of $5 \times$ reaction buffer, $0.25 \mu \mathrm{L}$ 
Table 1. Quantitative reverse transcription-PCR gene expression of blood PMNL isolated on $-14,7$, and $14 \mathrm{~d}$ around parturition in dairy cows fed either control $^{1}(\mathrm{CON})$ or excess energy (HE) during the dry period

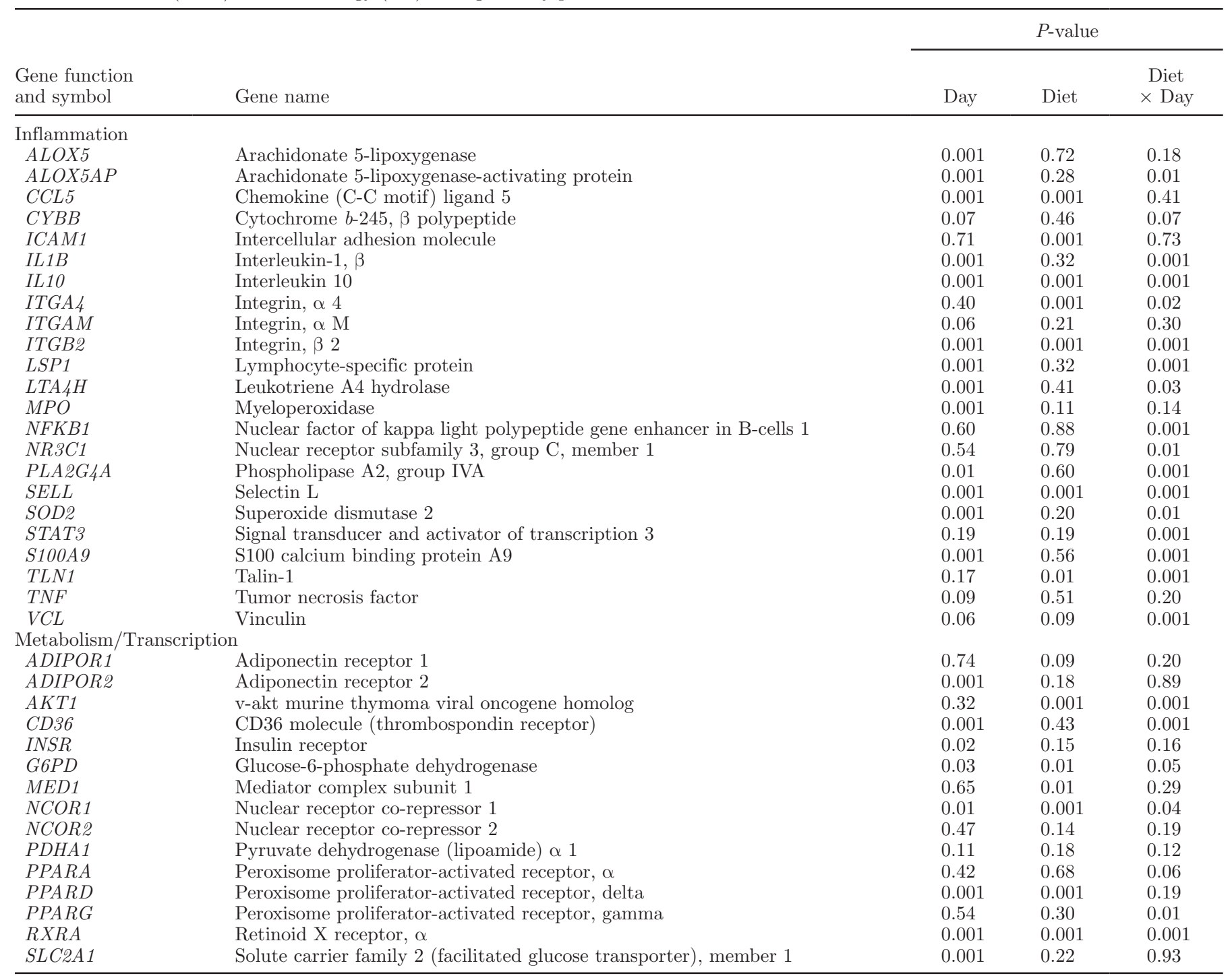

${ }^{1} \mathrm{CON}=1.34 \mathrm{Mcal} / \mathrm{kg}$ of DM, $\mathrm{n}=6 ; \mathrm{HE}=1.62 \mathrm{Mcal} / \mathrm{kg}$ of $\mathrm{DM}, \mathrm{n}=6$.

$(50 \mathrm{U})$ of RevertAid reverse transcriptase (Fermentas Inc., Glen Burnie, MD), and $0.25 \mu \mathrm{L}$ of RNase inhibitor (10 U, Promega, Madison, WI), was added.

Quantitative PCR was performed using $4 \mu \mathrm{L}$ of diluted cDNA combined with a mixture composed of $5 \mu \mathrm{L}$ of $1 \times$ SYBR Green master mix (Applied Biosystems, $\mathrm{CA}), 0.4 \mu \mathrm{L}$ of $10 \mu M$ forward and reverse primers each, and $0.2 \mu \mathrm{L}$ of DNase-/RNase-free water in a MicroAmp Optical 384-Well Reaction Plate (Applied Biosystems, Foster City, CA). Each sample was run in triplicate and a 6-point relative standard curve plus the nontemplate control was used (User Bulletin \#2, Applied Biosystems). The reactions were performed in an ABI Prism 7900 HT SDS instrument (Applied Biosystems) using the following conditions: $2 \mathrm{~min}$ at $50^{\circ} \mathrm{C}, 10 \mathrm{~min}$ at $95^{\circ} \mathrm{C}$,
40 cycles of $15 \mathrm{~s}$ at $95^{\circ} \mathrm{C}$ (denaturation), and $1 \mathrm{~min}$ at $60^{\circ} \mathrm{C}$ (annealing plus extension). Details of primer design and sequences have been reported previously (Moyes et al., 2014). The final data were normalized using the geometric mean of GAPDH, RPS9, and UXT, which were previously verified as suitable internal control genes (ICG; Moyes et al., 2014). The pairwise variation $(\mathrm{V} 2 / 3)$ of these ICG using geNorm was $<0.2$. Target genes were normalized with the geometric mean of the 3 ICG.

\section{Statistical Analysis}

Data were analyzed using the MIXED procedure in SAS (SAS Institute Inc., Cary, NC). Data were $\log -2$ 
transformed before statistical analysis. Fixed effects in the model included diet, day, and diet $\times$ day. Random effect was cow within diet. A repeated-measures statement using an autoregressive covariate structure was implemented. The means resulting from the statistical analysis were back-transformed for ease of interpretation (Moyes et al., 2014). Statistical differences were declared significant at $P \leq 0.05$ and tendencies at $P \leq$ 0.10 . Correlation analysis between gene expression data (after false discovery rate correction) and blood NEFA, BHBA, and insulin (Khan et al., 2014) was performed using PROC CORR of SAS (Supplemental Table S1; http://dx.doi.org/10.3168/jds.2014-8811). The expression of CCL2, LEPR, TLR4, and IL6 was deemed undetectable because the median cycle threshold was $>30$.

\section{RESULTS}

\section{Cytokines and Genes Associated with Inflammation}

The expression pattern of $I L 1 B$ was upregulated (diet $\times$ day, $P<0.01$ ), regardless of diet at 7 compared with $-14 \mathrm{~d}$. Cows in the HE group had greater (diet $\times$ day, $P<0.01)$ expression of $I L 1 B$ at -14 and $7 \mathrm{~d}$ compared with CON. Similar to $I L 1 B$, we detected a diet $\times$ day $(P<0.01)$ effect for $I L 10$ expression due to greater values in HE cows at -14 and $7 \mathrm{~d}$ that was followed by similar expression between groups at $14 \mathrm{~d}$. Furthermore, in CON cows, expression decreased (diet $\times$ day, $P<0.01$ ) on $\mathrm{d} 7$ compared with $-14 \mathrm{~d}$ and then increased to prepartal values on $\mathrm{d} 14$. In addition to greater $I L 1 B$ and $I L 10$ on d 7 , there was also greater expression of NFKB1 and STAT3 (diet $\times$ day, $P<$ 0.01) in $\mathrm{HE}$ cows compared with $\mathrm{CON}$ cows (Figure 1). Expression of $C C L 5$ decreased over time (day, $P<$ 0.01 ) and was affected by the prepartal dietary treatment (diet, $P<0.05$ ), with expression being greater in the HE group compared with CON.

Energy overfeeding before calving led to greater expression of $S 100 A 9$ (diet $\times$ day, $P<0.01$; Figure 1) and $M P O$ (diet $P=0.11$ ). Cows in the HE group also had greater expression of ALOX5AP and PLA2G4A prepartum and at $7 \mathrm{~d}$ (diet $\times$ day, $P<0.01$ ) compared with CON (Figure 2). Regardless of diet, expression of both genes was greater postpartum than prepartum $(P$ $<0.01$ ), with PLA2G4A reaching peak expression on $\mathrm{d}$ 14 in cows fed CON.

\section{Adhesion and Migration of PMNL}

Among genes associated with PMNL adhesion, motility, migration, and phagocytosis, we observed greater expression (diet $\times$ day, $P<0.01$ ) of SELL, ICAM1, ITGA4, ITGB2, LSP1, and TLN1 at $\mathrm{d}-14$ and 7 in HE compared with CON cows. Furthermore, expression of the cytoskeletal protein $V C L$ and myeloid related protein $S 100 A 9$ was also greater (diet $\times$ day, $P<0.01$ ) in $\mathrm{HE}$ compared with $\mathrm{CON}$ cows at $-14 \mathrm{~d}$. Except for ICAM1 and ITGA4, which remained greater in HE at $14 \mathrm{~d}$, the expression of other genes did not differ among groups at $14 \mathrm{~d}$. However, in cows fed CON, expression of SELL, LSP1, ITGB2, TLN1, and VCL increased (diet $\times$ day, $P<0.01$ ) between 7 and $14 \mathrm{~d}$ (Figure 3).

\section{Endocrine Signaling in PMNL}

The expression of INSR (Supplemental Table S1; http://dx.doi.org/10.3168/jds.2014-8811; Figure 4) decreased slightly (diet $\times$ day, $P<0.01$ ) in cows fed HE between -14 and $7 \mathrm{~d}$, but increased to prepartal values on $\mathrm{d} 14$, when it was greater than in cows fed CON. Cows in CON had a greater expression of AKT1 (diet $\times$ day, $P<0.01$ ) compared with cows in $\mathrm{HE}$ on $\mathrm{d}-14$ and 14 . The expression of ADIPOR 1 and ADIPOR2 was similar on $\mathrm{d}-14$ in $\mathrm{HE}$ and $\mathrm{CON}$; however, whereas ADIPOR2 was overall downregulated after calving (day, $P<0.01$ ) regardless of diet, cows fed CON compared with HE had lower (diet $\times$ day, $P<$ 0.01) ADIPOR 1 expression on d 7 (Figure 5).

\section{Nuclear Receptors and Inflammation}

The expression of PPARD showed a clear response to diet and day $(P<0.01)$. The overall pattern of expression of $R X R A$ was similar to that of PPARD, but feeding $\mathrm{HE}$ compared with CON led to greater expression (diet $\times$ day, $P<0.01$ ) before and after calving. In contrast, the expression of the co-regulators NCOR 1 and MED1 was overall lower (diet $\times$ day, $P<0.01$ ) in cows fed HE compared with CON. Expression of $P P A R A$ was not affected by diet, day, or their interaction, and the expression of $P P A R G$ had an interaction (diet $\times$ day, $P<0.01$ ) due to greater expression on $\mathrm{d}$ -14 in cows fed HE compared with CON.

\section{Glucose Metabolism and PMNL Immune Function}

The expression of PDHA1 was not affected by diet, day, or their interaction, whereas the expression of $G 6 P D$ had an interaction (diet $\times$ day, $P<0.05$ ) because of the greater overall expression in cows fed HE compared with CON (Figure 6) and greater expression at 7 (for $\mathrm{HE}$ ) and $14 \mathrm{~d}$ postpartum (for $\mathrm{CON}$ ) than prepartum. 


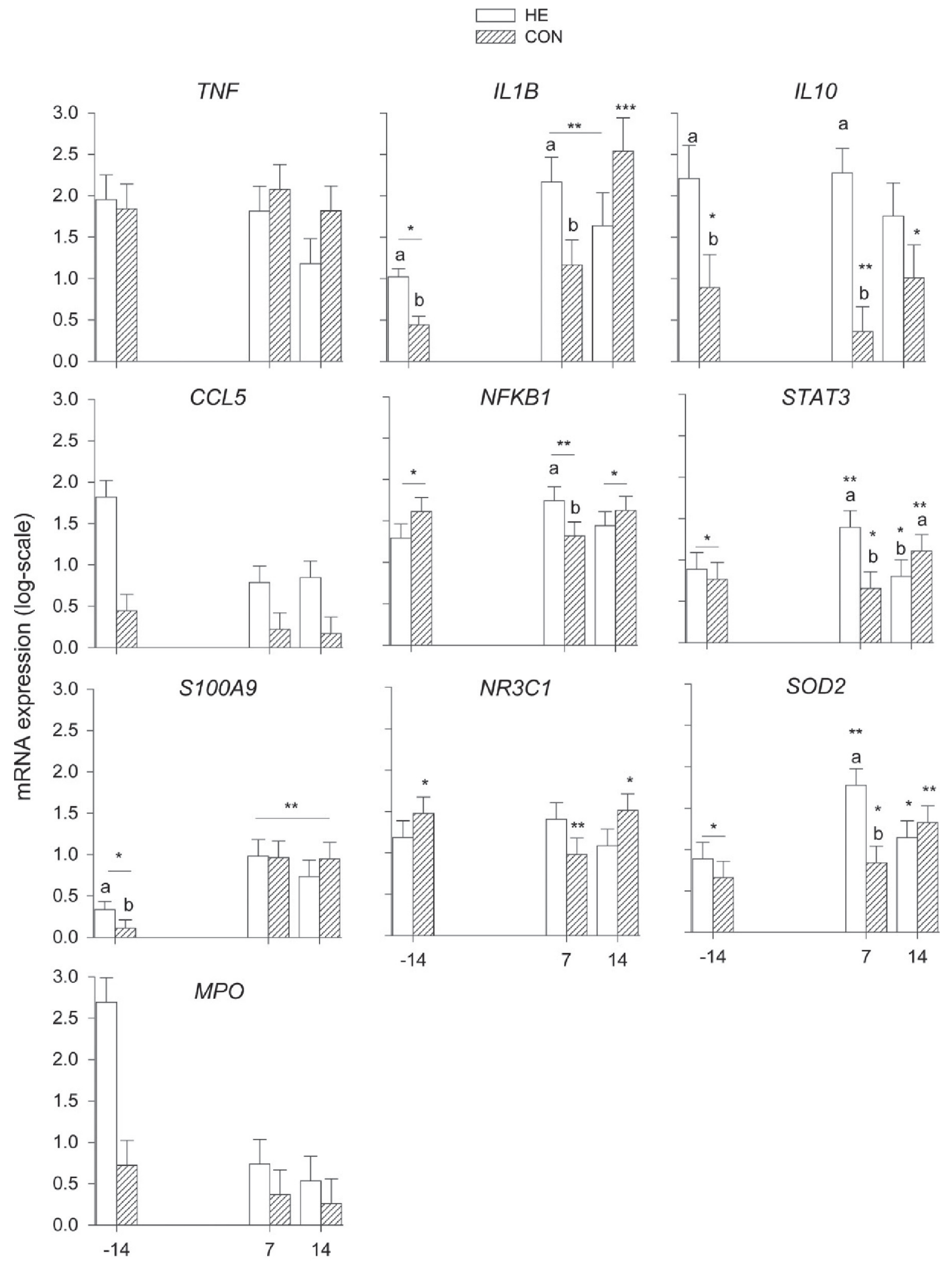

Day relative to parturition

Figure 1. Expression of genes associated with inflammation and oxidative stress in PMNL of cows fed a control-energy diet (CON) or a higher-energy diet $(\mathrm{HE})$ during the entire dry period. ${ }^{\mathrm{a}, \mathrm{b}}$ Diet $\times$ day effects $(P<0.05)$ at a specific time point; ${ }^{*, * *, * * *}$ diet $\times$ day effects $(P<0.05)$ within diet and across days. Error bars indicate SEM. 
$\square$ HE IIIIA CON
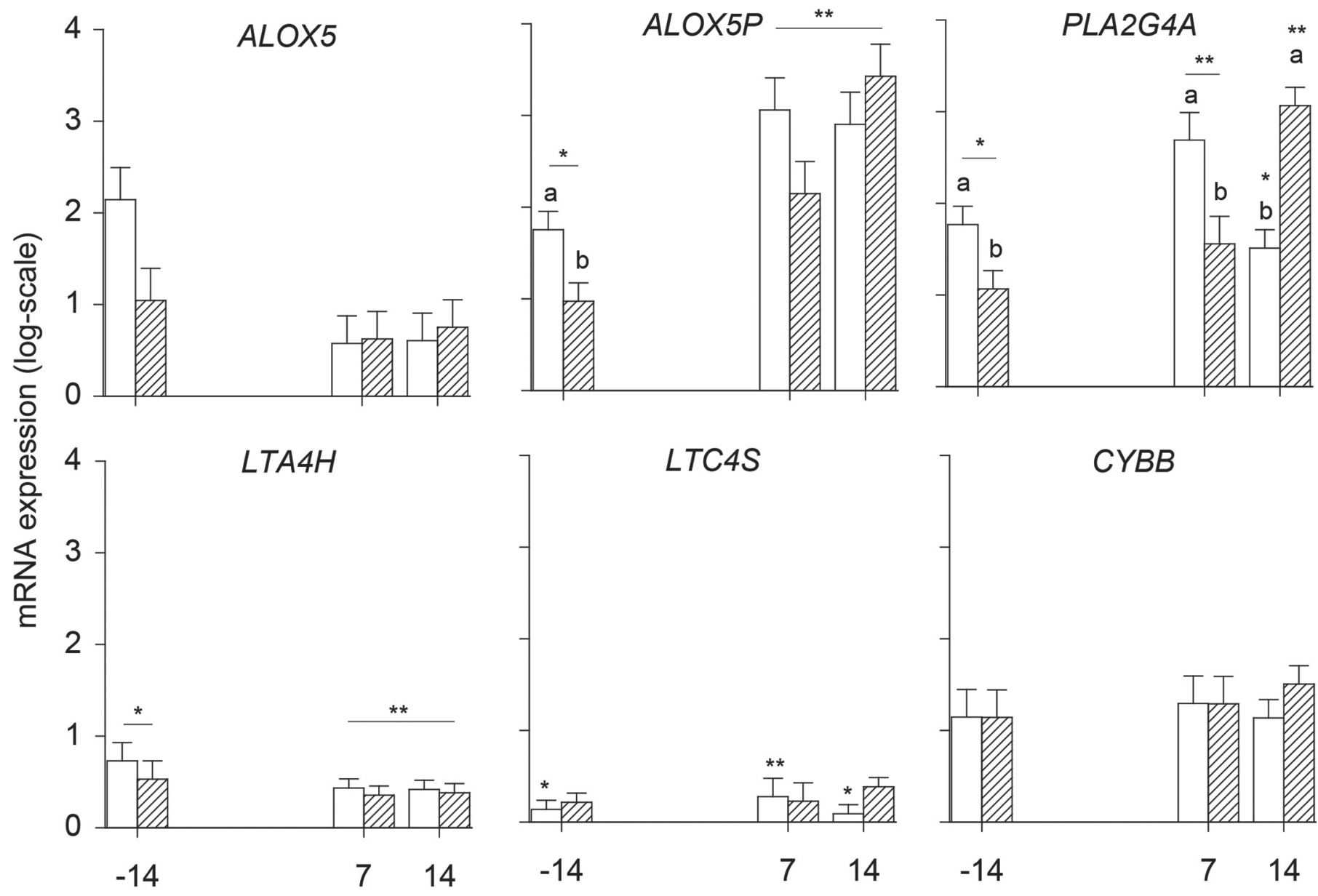

\section{Day relative to parturition}

Figure 2. Expression of genes associated with immune cell adhesion in PMNL of cows fed a control-energy diet (CON) or a higher-energy diet $(\mathrm{HE})$ during the entire dry period. ${ }^{\mathrm{a}, \mathrm{b}}$ Diet $\times$ day effects $(P<0.05)$ at a specific time point; ${ }^{*, * *}$ diet $\times$ day effects $(P<0.05)$ within diet and across days. Error bars indicate SEM.

\section{DISCUSSION}

Often during the transition period, the capacity for PMNL trafficking, phagocytosis, and pathogen killing is impaired (Kehrli et al., 1989), probably due to changes in hormones and metabolites and to immune or stress-like conditions (Mallard et al., 1998). Chronically elevated concentrations of BHBA and NEFA are associated with lower PMNL chemokine expression and chemotaxis (ex vivo; Suriyasathaporn et al., 1999), reduced viability (in vivo; Scalia et al., 2006), reduced respiratory burst (ex vivo; Hoeben et al., 1997), and reduced phagocytosis (ex vivo; Grinberg et al., 2008). The data generated in the present study helped evalu- ate PMNL gene expression patterns around parturition in response to prepartal dietary energy level as a way to better understand how metabolic changes in vivo may affect the innate immune system.

\section{Cytokines and Genes Associated with Inflammation}

Production of inflammatory cytokines such as IL-1 $\beta$ is increased in response to pro-inflammatory stimuli (Ramadori and Armbrust, 2001). In the current experiment, the upregulated $I L 1 B$ around calving appeared to correlate with the dramatic metabolic changes occurring during the transition period and suggested a 


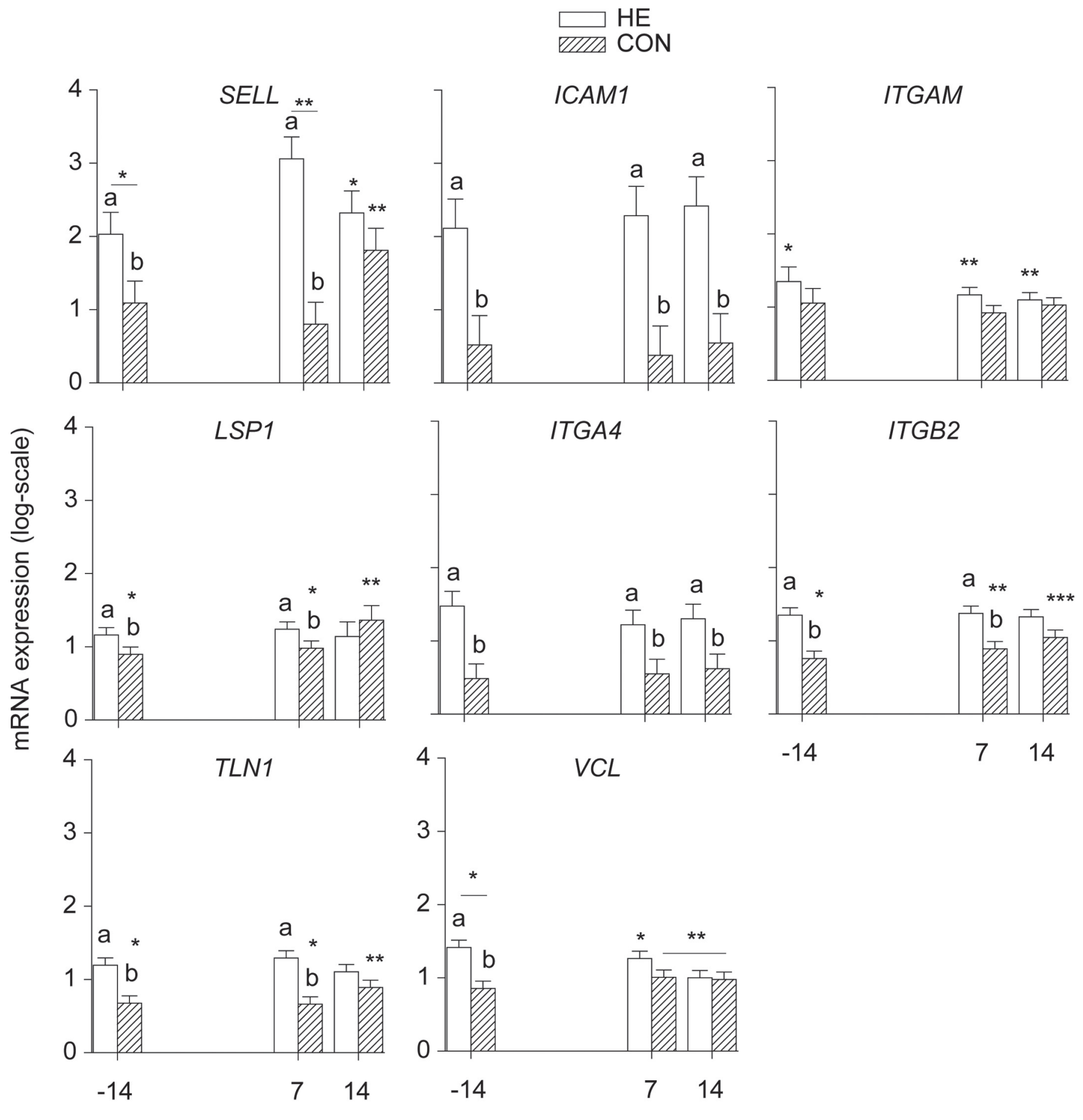

Day relative to parturition

Figure 3. Expression of genes associated with eicosanoid production in PMNL of cows fed a control-energy diet (CON) or a higher-energy diet $(\mathrm{HE})$ during the entire dry period. ${ }^{\mathrm{a}, \mathrm{b}}$ Diet $\times$ day effects $(P<0.05)$ at a specific time point; ${ }^{*, * * * * * *}$ diet $\times$ day effects $(P<0.05)$ within diet and across days. Error bars indicate SEM. 

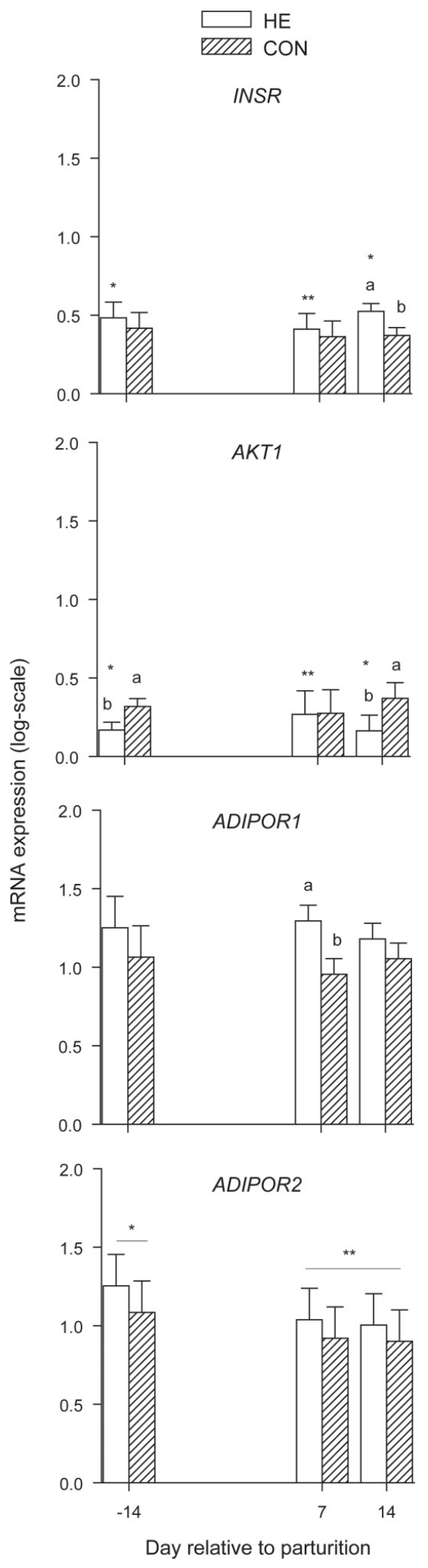

Figure 4. Expression of genes associated with insulin and adipokine signaling in PMNL of cows fed a control-energy diet (CON) or a higher-energy diet (HE) during the entire dry period. ${ }^{\mathrm{a}, \mathrm{b}}$ Diet $\times$ day effects $(P<0.05)$ at a specific time point; ${ }^{*},{ }^{* *}$ diet $\times$ day effects $(P<$ $0.05)$ within diet and across days. Error bars indicate SEM. higher degree of inflammation before and around parturition in the HE group.

Neutrophils represent a key target of IL10 and this cytokine is of extreme importance in controlling the degree and duration of the inflammatory reactions (Bazzoni et al., 2010). Results from human studies demonstrated higher production of IL-10 in pregnancy (Marzi et al., 1996). To our knowledge, there are no published data on bovine blood IL-10 concentrations around parturition but it is possible that HE compared with CON cows maintained consistently greater IL10 expression as a result of the greater concentrations of NEFA and BHBA in blood (Khan et al., 2014), both of which can have deleterious effects on PMNL function.

The chemokine CCL5 plays an important role in leukocyte migration and chemotaxis in response to stimuli, including IL-1 $\beta$, tumor necrosis factor, and LPS (Moser et al., 2004). Because HE cows had overall greater concentrations of glucose around calving compared with CON cows (Khan et al., 2014), upregulation of CCL5 might be a mechanism to allow PMNL to utilize glucose as an energy source (Pithon-Curi et al., 2004). Thus, the overall decrease in CCL5 postcalving could be explained by the preferential use of glucose by mammary gland for milk synthesis.

The protein S100A9 is involved in the control of PMNL oxidative metabolism (Bréchard et al., 2013), respiratory burst, and extracellular trap-mediated microbial killing (Parker and Winterbourn, 2013). Along with myeloperoxidase (MPO), it is also involved in NADPH oxidase activity, which converts superoxide anion radicals to $\mathrm{H}_{2} \mathrm{O}_{2}$. Thus, the greater expression of $S 100 A 9$ prepartum conflicts with the lower PMNL phagocytosis reported for HE- compared with CONfed cows (Graugnard et al., 2012). However, the increase in $S 100 A 9$ postpartum agrees with the marked increase in PMNL phagocytosis in HE cows after calving (Graugnard et al., 2012). The observation that S100A8/A9 promotes NADPH oxidase activation ex vivo (Kerkhoff, 2005) suggests that S100A9 upregulation postpartum in the present study may have enhanced NADPH oxidase activity during phagocytosis (Bréchard et al., 2013).

Arachidonic acid concentration was $\sim 17 \%$ of total PMNL fatty acids in human patients with an inflammatory disorder, whereas the concentration was $\sim 3 \%$ in healthy humans (Klock and Pieprzyk, 1979). Generation of arachidonic acid via key enzymes such as PLA2G4A (Funk, 2001) and ALOX5AP (Stephensen et al., 2011) is essential for the activation of NADPH oxidase (Pessach et al., 2001). In the current study, the upregulation of these 2 genes in HE cows suggests that, prepartum, the HE diet led to greater release of arachidonic acid from PMNL membranes and subsequent 
$\square \mathrm{HE}$

WIII CON
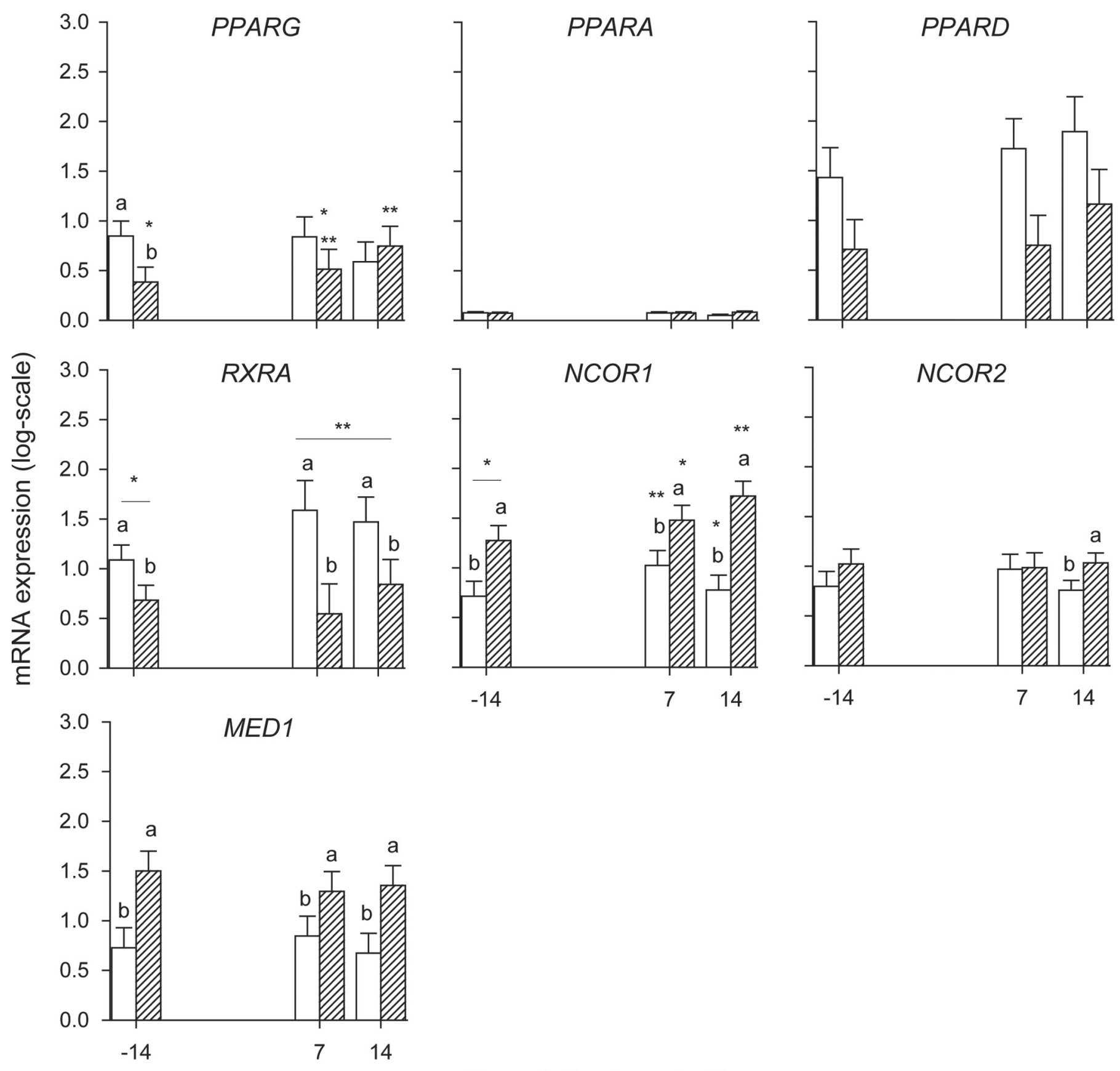

\section{Day relative to parturition}

Figure 5. Expression of genes associated with peroxisome proliferator-activated receptor (PPAR) signaling in PMNL of cows fed a controlenergy diet $(\mathrm{CON})$ or a higher-energy diet $(\mathrm{HE})$ during the entire dry period. ${ }^{\mathrm{a}, \mathrm{b}}$ Diet $\times$ day effects $(P<0.05)$ at a specific time point; ${ }^{* * * *}$ diet $\times$ day effects $(P<0.05)$ within diet and across days. Error bars indicate SEM.

synthesis of proinflammatory eicosanoids. Further research is needed to measure the direct influence of intracellular eicosanoids on expression of $I L 1 B, I L 10$,
S100A9, MPO, and SELL, the upregulation of which denotes a more pronounced activation of the immune response. 
The postpartal upregulation of most of these genes regardless of prepartal dietary energy is suggestive of additional factors (e.g., change in hormonal environment, oxidative stress) in the postpartum period stimulating the coordinated production of intracellular signaling molecules that help maintain some degree of inflammation. For instance, cows fed HE had increased expression of SOD2 and greater NEFA concentration (Khan et al., 2014) postpartum compared with CON cows, indicating a more pronounced state of oxidative stress (Bernabucci et al., 2005). Increased production of $\mathrm{H}_{2} \mathrm{O}_{2}$ during PMNL phagocytosis is associated with higher expression of SOD2 (Olsson et al., 2011). Nonetheless, the marked decrease in $M P O$ postpartum suggests a lesser contribution of this enzyme to $\mathrm{H}_{2} \mathrm{O}_{2}$ catabolism. More research is needed to determine whether these changes in mRNA expression also occur at the protein level, particularly for myeloperoxidase, which is secreted from PMNL during inflammation.

Previous work (Graugnard et al., 2012) on prepartal energy nutrition revealed that cows fed HE diets have lower prepartal PMNL phagocytosis along with greater insulin concentrations (Khan et al., 2014) in blood. Thus, the expression profiles of $I L 1 B$ and $I L 10$ in the present study suggest that the high insulin prepartum in HE cows might have dampened the PMNL function, resulting in delayed phagocytosis. Such an effect could have led to upregulation of the genes encoding pro- and anti-inflammatory cytokines as well as important antiinflammatory proteins (S100A9 and MPO; Figure 1).

The current findings suggest that feeding strategies along with management practices to increase cow comfort during parturition may help stabilize PMNL activity before calving, as an activated population of PMNL before parturition may alter regulation after parturition and, thus, may not be ideal. However, our previous data (Graugnard et al., 2012) revealed an increase in PMNL phagocytosis in HE cows during the first week postcalving, partly as a function of greater glucose concentration but also because of the upregulation of $I L 1 B$ and the transcription regulators $N F K B 1$ and STAT3 (Figure 1).

\section{Adhesion and Migration of PMNL}

Multiple genes are involved in the adhesion and migration of PMNL. Strikingly, the pattern of most of these genes (SELL, ICAM1, ITGA4, ITGB2, LSP1, and TLN1) was similar to that of $I L 1 B, I L 10, N F K B 1$, and STAT3, which together suggested a more chronic state of inflammation during the transition period in the HE group. The higher expression of S100A9 in HE cows prepartum suggests stimulation of PMNL activation via enhanced adhesion. In fact, the overall pattern
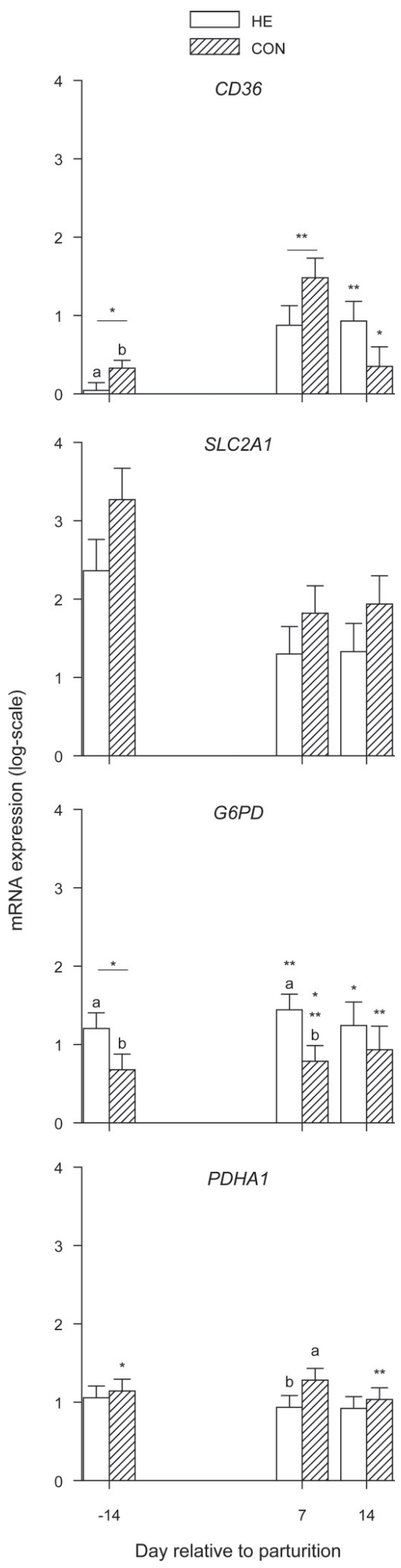

Figure 6. Expression of genes associated with fatty acid and glucose metabolism in PMNL of cows fed a control-energy diet (CON) or a higher-energy diet (HE) during the entire dry period. ${ }^{\mathrm{a}, \mathrm{b}}$ Diet $\times$ day effects $(P<0.05)$ at a specific time point; ${ }^{*, * *}$ diet $\times$ day effects $(P<$ $0.05)$ within diet and across days. Error bars indicate SEM. 
of expression of SELL and other genes associated with adhesion, motility, and PMNL phagocytosis seems to suggest that inflammatory stimuli induced by feeding HE prepartum also led to overall activation of the PMNL; that is, unlike in previous in vitro work (Scalia et al., 2006), the greater NEFA induced by feeding HE did not seem to compromise PMNL function. However, it is noteworthy that in cows fed CON, the PMNL had a delayed response in terms of immune response activation; that is, several genes examined were upregulated between 7 and $14 \mathrm{~d}$. The mechanisms responsible for such a response are unclear.

\section{Endocrine Signaling in PMNL}

In the present study, the responses in expression of INSR and AKT1 induced by feeding HE compared with CON on -14 and $7 \mathrm{~d}$ might be related to the differences in blood insulin concentration (Khan et al., 2014); that is, greater INSR to accommodate the greater blood insulin in HE prepartum. Conversely, cows in HE had lower insulin concentrations but greater AKT1 during the first week postpartum. The insulin-responsive glucose transporter SLC2A4 was not evaluated; thus, it remains unclear if the changes in circulating insulin around calving have a functional relevance to glucose utilization by PMNL.

Plasma concentration of total adiponectin typically decreases from -14 through $14 \mathrm{~d}$ around parturition (Kabara et al., 2014; Singh et al., 2014), and gradually increases thereafter to prepartal levels by $\sim 30 \mathrm{~d}$ postpartum (Singh et al., 2014). In vitro data with human neutrophils demonstrated that neutrophil phagocytosis of Escherichia coli was inhibited by adiponectin (Rossi and Lord, 2014). Although we did not measure serum or plasma adiponectin in our study, the fact that HEfed cows have greater adipose tissue $A D I P O Q$ expression (Ji et al., 2012) around calving and their PMNL have greater ADIPOR 1 on d 7 compared with $\mathrm{CON}$ suggest that this adipokine may play a role in immune function. As such, it may serve to attenuate the proinflammatory response driven by energy overfeeding.

\section{Nuclear Receptors and Inflammation}

Peroxisome proliferator-activated receptors (PPAR) are ligand-activated transcription factors, and the 3 PPAR isotypes ( $\alpha, \gamma$, and $\delta$ ) respond to long-chain NEFA (Bensinger and Tontonoz, 2008). Compared with control, HE cows had a greater and prolonged release of fatty acids from adipose tissue mobilization, which may activate and change expression of PPAR $\alpha$ or PPAR $\gamma$ and target genes in different tissues (Kadegowda et al., 2009; Bionaz et al., 2012). Activated PPAR play a role during the inflammatory process by inhibiting proinflammatory transcription factor signaling pathways in vascular and inflammatory cells in nonruminants (Moraes et al., 2006) or decreasing immune cell recruitment by inhibiting the release of chemokines (Murao et al., 1999; Lee et al., 2000).

Previous data revealed that 16:0 activates PPAR $\gamma$ in bovine mammary cells (Kadegowda et al., 2009). More recently, it was reported that both 16:0 and 18:0 could upregulate the expression of PPAR $\alpha$ and target genes in bovine kidney cells (Bionaz et al., 2012). No such data exist for PPARD, but we recently demonstrated that an acute LPS challenge early postpartum led to a marked increase in plasma NEFA along with upregulation of $P P A R D$ and several pro-inflammatory genes (TNF, NFKB1, TLR 4, and SOD2) in liver, suggesting that $P P A R D$ is more closely related to immune function than are the other isotypes (Graugnard et al., 2013). Unlike liver during an LPS challenge, the greater PPARD expression in $\mathrm{HE}$ did not seem to be related to $T N F$ expression but rather followed a similar pattern as IL1B, IL10, NFKB1, and STAT3.

In the physiological context, it is unclear if PMNL actively take up (via diffusion or membrane transporters) and metabolize NEFA from the circulation. The correlation of NEFA and CD36 (Supplemental Table S1; http://dx.doi.org/10.3168/jds.2014-8811) suggests that PMNL can uptake NEFA, but the fact that in vitro concentrations of up to $1 \mathrm{mmol} / \mathrm{L}$ did not affect PMNL phagocytosis, oxidative burst, or viability, along with the modest effect on CD36, suggest that, in vivo, PMNL do not actively take up NEFA. In contrast, the overall greater expression of SLC2A1 compared with CD36 supports the view that glucose is a primary energy source for PMNL (Pithon-Curi et al., 2004). Furthermore, the fact that inflammation markedly increases the concentration of arachidonic acid in PMNL (Klock and Pieprzyk, 1979) suggests that eicosanoids or leukotrienes derived from arachidonic acid are more biologically relevant in terms of modulating the PPARRXRA signaling network. For instance, leukotrienes (e.g., leukotriene B4) derived from arachidonic acid during inflammation can activate PPAR with a subsequent increase in expression and production of IL-10, which is extremely important to prevent the onset of a chronic inflammatory condition (Buckley et al., 2014). The lower overall NCOR1 expression in PMNL from HE cows supports the idea of a more active state of the PPAR-RXRA in those cows.

Different genes are involved in the control of intracellular leukotriene concentrations, such as PLA2G4A (Holinstat et al., 2011), ALOX5 and ALOX5AP (Stephensen et al., 2011), and LTA $4 H$ and $L T C 4 S$. The leukotrienes play a role in PMNL adhesion and phago- 
cytosis (Evans et al., 1986; Kasirga et al., 1999), but their intracellular concentrations must be controlled to prevent cell damage. The fact that expression of $L T A 4 H$ decreased after calving regardless of diet and that expression of $L T C 4 S$ was slightly upregulated postcalving by feeding $\mathrm{HE}$ suggests that leukotriene production by PMNL might not be as physiologically relevant as the utilization of arachidonic acid for synthesis of prostaglandins and eicosanoids that can activate PPAR (Stephensen et al., 2011; Buckley et al., 2014). Direct measurement of prostaglandin and eicosanoid production will be helpful to validate this hypothesis.

\section{Glucose Metabolism and PMNL Immune Function}

As a result of metabolism of glucose to lactate (Beck and Valentine, 1952; Borregaard and Herlin, 1982), all leukocytes are capable of tricarboxylic acid cycling (Stjernholm, 1967). However, PMNL oxidize only 2 to $3 \%$ of the glucose taken up via the tricarboxylic acid cycle (Beck, 1958; Wood et al., 1963). The lack of changes in the expression of PDHA1 agrees with the lesser importance of the tricarboxylic acid cycle in PMNL.

Glucose metabolism is strictly connected to the production of reactive oxygen species during oxidative burst, mainly through the pentose phosphate pathway (PPP; Borregaard et al., 1984). Activity through the PPP produces the electrons for the NADPH oxidase enzyme and the protons released in association with the respiratory burst (Borregaard et al., 1984). The expression of G6PD, first step and rate-limiting enzyme of the pathway (Wood, 1985), agrees with the genes related to oxidative stress (S100A9, SOD2). The increase in $G 6 P D$ postpartum (day, $P<0.05$ ) is likely related to greater PMNL activity to satisfy the NADPH and proton requirements. In cows fed HE, the greater expression of G6PD and SOD2 suggests a higher PMNL phagocytosis both pre- and postpartum, an idea also supported by the higher glucose levels in HE cows (Khan et al., 2014). The expression of PDAH1 suggests that the greater concentration of glucose was not diverted to oxidation in the tricarboxylic acid cycle, but rerouted to the PPP, increasing PMNL activity.

Higher prepartum levels of insulin (Khan et al., 2014) may help enhance PMNL function and glucose6-phosphate dehydrogenase (G6PD) activity. For instance, Alba-Loureiro et al. (2006) postulated possible direct effects on PMNL metabolism and function in rats. The PPP is also used by the cells to produce ribose-5-phosphate, an important precursor in de novo synthesis of nucleotides. As expression of many genes in PMNL increases around parturition, a role of G6PD in regulating the PPP to support the need for nucleotides for RNA transcription could be hypothesized.

\section{CONCLUSIONS}

Immune function-related disorders are among the most prevalent and economically relevant health issues afflicting periparturient dairy cows. Blood PMNL represent an important defense against invading pathogens; thus, their functionality and activity are crucial for the wellbeing of the animal. During the transition period, the cow experiences alterations in its pathogen defense mechanisms (e.g., PMNL), possibly associated with changes in hormone profiles and metabolic and physical stresses of parturition. The present study revealed that allowing cows free access to higher-energy diets during late pregnancy, a common management practice in the dairy industry, resulted in the alteration of genes encompassing pathways of inflammation in PMNL. Future research must measure whether such alterations could alter PMNL function. More importantly, the greater expression of inflammation-related genes ahead of parturition could be explained by the chronic overconsumption of energy, an effect that has been demonstrated in humans. Whether the activation of inflammation within PMNL interferes with an optimal transition to lactation remains to be determined. These adaptations in PMNL did not seem to be detrimental to production (Khan et al., 2014) or health (i.e., clinical disease); however, more specific research is required to determine whether they are of physiological relevance.

\section{ACKNOWLEDGMENTS}

Financial support for portions of this work was provided by National Research Initiative competitive grant 2007-35204-17758, NIFA (Washington, DC; ILLU-538914), and grants from the Chinese Ministry of Science and Technology (Beijing, China; 2012BAD12B02-5) and the Chinese Agricultural Science and Technology Innovation Program (Beijing, China; ASTIP-IAS07).

\section{REFERENCES}

Alba-Loureiro, T. C., S. M. Hirabara, J. R. Mendonça, R. Curi, and T. C. Pithon-Curi. 2006. Diabetes causes marked changes in function and metabolism of rat neutrophils. J. Endocrinol. 188:295-303.

Bazzoni, F., N. Tamassia, M. Rossato, and M. A. Cassatella. 2010 Understanding the molecular mechanisms of the multifaceted IL10-mediated anti-inflammatory response: Lessons from neutrophils. Eur. J. Immunol. 40:2360-2368.

Beck, W. S. 1958. Occurrence and control of the phosphogluconate oxidation pathway in normal and leukemic leukocytes. J. Biol. Chem. 232:271-283. 
Beck, W. S., and W. N. Valentine. 1952. The aerobic metabolism of leukocytes in health and leukemia. I. Glycolysis and respiration. Cancer Res. 12:818-822.

Bensinger, S. J., and P. Tontonoz. 2008. Integration of metabolism and inflammation by lipid-activated nuclear receptors. Nature 454:470-477.

Bernabucci, U., B. Ronchi, N. Lacetera, and A. Nardone. 2005. Influence of body condition score on relationships between metabolic status and oxidative stress in periparturient dairy cows. J. Dairy Sci. 88:2017-2026.

Bionaz, M., B. J. Thering, and J. J. Loor. 2012. Fine metabolic regulation in ruminants via nutrient-gene interactions: Saturated longchain fatty acids increase expression of genes involved in lipid metabolism and immune response partly through PPAR- $\alpha$ activation. Br. J. Nutr. 107:179-191.

Borregaard, N., and T. Herlin. 1982. Energy metabolism of human neutrophils during phagocytosis. J. Clin. Invest. 70:550-557.

Borregaard, N., J. H. Schwartz, and A. I. Tauber. 1984. Proton secretion by stimulated neutrophils. Significance of hexose monophosphate shunt activity as source of electrons and protons for the respiratory burst. J. Clin. Invest. 74:455-459.

Bréchard, S., S. Plançon, and E. J. Tschirhart. 2013. New insights into the regulation of neutrophil NADPH oxidase activity in the phagosome: A focus on the role of lipid and $\mathrm{Ca}^{2+}$ signaling. Antioxid. Redox Signal. 18:661-676.

Buckley, C. D., D. W. Gilroy, and C. N. Serhan. 2014. Proresolving lipid mediators and mechanisms in the resolution of acute inflammation. Immunity 40:315-327.

Burton, J. L., S. A. Madsena, L. C. Changa, P. S. D. Webera, K. R. Buckhama, R. van Dorpb, M. C. Hickeyc, and B. Earley. 2005. Gene expression signatures in neutrophils exposed to glucocorticoids: A new paradigm to help explain "neutrophil dysfunction" in parturient dairy cows. Vet. Immunol. Immunopathol. 105:197219.

Dann, H. M., N. B. Litherland, J. P. Underwood, M. Bionaz, A. D'Angelo, J. W. McFadden, and J. K. Drackley. 2006. Diets during far-off and close-up dry periods affect periparturient metabolism and lactation in multiparous cows. J. Dairy Sci. 89:3563-3577.

Evans, J., D. Nathaniel, S. Charleson, C. Leveille, R. Zamboni, Y. Leblanc, R. Frenette, B. J. Fitzsimmons, S. Leger, P. Hamel, and A. W. Ford-Hutchinson. 1986. Neutrophil LTA4 hydrolases and leukotriene B4 receptors: Effects of leukotriene epoxides and their enzymatic products. Prostaglandins Leukot. Med. 23:167-171.

Funk, C. D. 2001. Prostaglandins and leukotrienes: Advances in eicosanoid biology. Science 294:1871-1875.

Goldsby, R. A., R. J. Kindt, and B. A. Osborne. 2000. Kuby Immunology. 4th ed. W. H. Freeman and Company, New York, NY.

Graugnard, D. E., M. Bionaz, E. Trevisi, K. M. Moyes, J. L. SalakJohnson, R. L. Wallace, J. K. Drackley, G. Bertoni, and J. J. Loor. 2012. Blood immunometabolic indices and polymorphonuclear neutrophil function in peripartum dairy cows are altered by level of dietary energy prepartum. J. Dairy Sci. 95:1749-1758.

Graugnard, D. E., K. M. Moyes, E. Trevisi, M. J. Khan, D. Keisler, J. K. Drackley, G. Bertoni, and J. J. Loor. 2013. Liver lipid content and inflammometabolic indices in peripartal dairy cows are altered in response to prepartal energy intake and postpartal intramammary inflammatory challenge. J. Dairy Sci. 96:918-935.

Grinberg, N., S. Elazar, I. Rosenshine, and N. Y. Shpigel. 2008. Betahydroxybutyrate abrogates formation of bovine neutrophil extracellular traps and bactericidal activity against mammary pathogenic Escherichia coli. Infect. Immun. 76:2802-2807.

Grummer, R. R. 1995. Impact of changes in organic nutrient metabolism on feeding the transition dairy cow. J. Anim. Sci. 73:28202833.

Hoeben, D., R. Heyneman, and C. Burvenich. 1997. Elevated levels of beta-hydroxybutyric acid in periparturient cows and in vitro effect on respiratory burst activity of bovine neutrophils. Vet. Immunol. Immunopathol. 58:165-170.

Holinstat, M., O. Boutaud, P. L. Apopa, J. Vesci, M. Bala, J. A. Oates, and H. E. Hamm. 2011. Protease-activated receptor signaling in platelets activates cytosolic phospholipase A2alpha differ- ently for cyclooxygenase-1 and 12-lipoxygenase catalysis. Arterioscler. Thromb. Vasc. Biol. 31:435-442.

Ji, P., J. S. Osorio, J. K. Drackley, and J. J. Loor. 2012. Overfeeding a moderate energy diet prepartum does not impair bovine subcutaneous adipose tissue insulin signal transduction and induces marked changes in peripartal gene network expression. J. Dairy Sci. 95:4333-4351.

Kabara, E., L. M. Sordillo, S. Holcombe, and G. A. Contreras. 2014. Adiponectin links adipose tissue function and monocyte inflammatory responses during bovine metabolic stress. Comp. Immunol. Microbiol. Infect. Dis. 37:49-58.

Kadegowda, A. K., M. Bionaz, L. S. Piperova, R. A. Erdman, and J. J. Loor. 2009. Peroxisome proliferator-activated receptor-gamma activation and long-chain fatty acids alter lipogenic gene networks in bovine mammary epithelial cells to various extents. J. Dairy Sci. 92:4276-4289.

Kasirga, E., I. Coker, S. Aydogdu, R. V. Yagci, B. Taneli, and A. Gousseinov. 1999. Blood levels of leukotrienes (LTC4, D4, E4, B4) and synthesis of leukotriene B4 by peripheral leukocytes in children with acute A and B hepatitis. Turk. J. Pediatr. 41:457-465.

Kehrli, M. E. Jr., B. J. Nonnecke, and J. A. Roth. 1989. Alterations in bovine neutrophil function during the periparturient period. Am. J. Vet. Res. 50:207-214.

Khan, M. J., C. B. Jacometo, D. E. Graugnard, M. N. Corrêa, E. Schmitt, F. Cardoso, and J. J. Loor. 2014. Overfeeding dairy cattle during late-pregnancy alters hepatic PPAR $\alpha$-regulated pathways including hepatokines: Impact on metabolism and peripheral insulin sensitivity. Gene Regul. Syst. Bio. 8:97-111.

Klock, J. C., and J. K. Pieprzyk. 1979. Cholesterol, phospholipids, and fatty acids of normal immature neutrophils: Comparison with acute myeloblastic leukemia cells and normal neutrophils. J. Lipid Res. 20:908-911.

Lee, H., W. Shi, P. Tontonoz, S. Wang, G. Subbanagounder, C. C. Hedrick, S. Hama, C. Borromeo, R. M. Evans, J. A. Berliner, and L. Nagy. 2000. Role for peroxisome proliferator-activated receptor alpha in oxidized phospholipid-induced synthesis of monocyte chemotactic protein-1 and interleukin- 8 by endothelial cells. Circ. Res. 87:516-521.

Mallard, B. A., J. C. Dekkers, M. J. Ireland, K. E. Leslie, S. Sharif, C. L. Vankampen, L. Wagter, and B. N. Wilkie. 1998. Alteration in immune responsiveness during the peripartum period and its ramification on dairy cow and calf health. J. Dairy Sci. 81:585-595.

Marzi, M., A. Vigano, D. Trabattoni, M. L. Villa, A. Salvaggio, E. Clerici, and M. Clerici. 1996. Characterization of type 1 and type 2 cytokine production profile in physiologic and pathologic human pregnancy. Clin. Exp. Immunol. 106:127-133.

Moraes, L. A., L. Piqueras, and D. Bishop-Bailey. 2006. Peroxisome proliferator-activated receptors and inflammation. Pharmacol. Ther. 110:371-385.

Moser, B., M. Wolf, A. Walz, and P. Loetscher. 2004. Chemokines: Multiple levels of leukocyte migration control. Trends Immunol. 25:75-84.

Moyes, K. M., J. K. Drackley, J. L. Salak-Johnson, D. E. Morin, J. C. Hope, and J. J. Loor. 2009. Dietary-induced negative energy balance has minimal effects on innate immunity during a Streptococcus uberis mastitis challenge in dairy cows during midlactation. J. Dairy Sci. 92:4301-4316.

Moyes, K. M., D. E. Graugnard, M. J. Khan, M. Mukesh, and J. J. Loor. 2014. Postpartal immunometabolic gene network expression and function in blood neutrophils are altered in response to prepartal energy intake and postpartal intramammary inflammatory challenge. J. Dairy Sci. 97:2165-2177.

Murao, K., H. Imachi, A. Momoi, Y. Sayo, H. Hosokawa, M. Sato, T. Ishida, and J. Takahara. 1999. Thiazolidinedione inhibits the production of monocyte chemoattractant protein-1 in cytokinetreated human vascular endothelial cells. FEBS Lett. 454:27-30.

Olsson, J., T. A. Jacobson, J. M. Paulsson, E. Dadfar, A. Moshfegh, S H. Jacobson, and J. Lundahl. 2011. Expression of neutrophil SOD2 is reduced after lipopolysaccharide stimulation: a potential cause of neutrophil dysfunction in chronic kidney disease. Nephrol. Dial. Transplant. 26:2195-2201. 
Oviedo-Boyso, J., J. J. Valdez-Alarcon, M. Cajero-Juarez, A. OchoaZarzosa, J. E. Lopez-Meza, A. Bravo-Patino, and V. M. Baizabal-Aguirre. 2007. Innate immune response of bovine mammary gland to pathogenic bacteria responsible for mastitis. J. Infect. 54:399-409.

Paape, M. J., D. D. Bannerman, X. Zhao, and J. W. Lee. 2003. The bovine neutrophil: Structure and function in blood and milk. Vet. Res. 34:597-627.

Parker, H., and C. C. Winterbourn. 2013. Reactive oxidants and myeloperoxidase and their involvement in neutrophil extracellular traps. Front Immunol. 3:424. http://dx.doi.org/10.3389/ fimmu.2012.00424.

Pessach, I., T. L. Leto, H. L. Malech, and R. Levy. 2001. Essential requirement of cytosolic phospholipase $\mathrm{A}(2)$ for stimulation of NADPH oxidase-associated diaphorase activity in granulocyte-like cells. J. Biol. Chem. 276:33495-33503.

Pithon-Curi, T. C., M. P. De Melo, and R. Curi. 2004. Glucose and glutamine utilization by rat lymphocytes, monocytes and neutrophils in culture: A comparative study. Cell Biochem. Funct. $22: 321-326$.

Ramadori, G., and T. Armbrust. 2001. Cytokines in the liver. Eur. J. Gastroenterol. Hepatol. 13:777-784.

Rossi, A., and J. Lord. 2013. Adiponectin inhibits neutrophil phagocytosis of Escherichia coli by inhibition of PKB and ERK 1/2 MAPK signalling and Mac-1 activation. PLoS ONE 8:e69108.

Scalia, D., N. Lacetera, U. Bernabucci, K. Demeyere, L. Duchateau, and C. Burvenich. 2006. In vitro effects of nonesterified fatty acids on bovine neutrophils oxidative burst and viability. J. Dairy Sci. $89: 147-154$.
Singh, S. P., S. Häussler, J. J. Gross, F. J. Schwarz, R. M. Bruckmaier, and H. Sauerwein. 2014. Short communication: Circulating and milk adiponectin change differently during energy deficiency at different stages of lactation in dairy cows. J. Dairy Sci. 97:15351542 .

Sordillo, L. M., K. Shafer-Weaver, and D. DeRosa. 1997. Immunobiology of the mammary gland. J. Dairy Sci. 80:1851-1865.

Stephensen, C. B., P. Armstrong, J. W. Newman, T. L. Pedersen, J. Legault, G. U. Schuster, D. Kelley, S. Vikman, J. Hartiala, R. Nassir, M. F. Seldin, and H. Allayee. 2011. ALOX5 gene variants affect eicosanoid production and response to fish oil supplementation. J. Lipid Res. 52:991-1003.

Stjernholm, R. L. 1967. Carbohydrate metabolism in leukocytes: VII. Metabolism of glucose, acetate, and propionate by human plasma cells. J. Bacteriol. 93:1657-1661.

Suriyasathaporn, W., A. J. Daemen, E. N. Noordhuizen-Stassen, S. J. Dieleman, M. Nielen, and Y. H. Schukken. 1999. Beta-hydroxybutyrate levels in peripheral blood and ketone bodies supplemented in culture media affect the in vitro chemotaxis of bovine leukocytes. Vet. Immunol. Immunopathol. 68:177-186.

USDA. 2008. Dairy 2007, Part II: Changes in the U.S. Dairy Cattle Industry, 1991-2007. \#N481.0308. USDA-APHIS-VS, CEAH, Fort Collins, CO.

Wood, H. G., J. Katz, and B. R. Landau. 1963. Estimation of pathways of carbohydrate metabolism. Biochem. Z. 338:809-847.

Wood, T. 1985. The Pentose Phosphate Pathway. Academic Press, Orlando, FL. 